\title{
Optimal Power Flow Menggunakan Metode Interior Point yang Disempurnakan
}

\author{
Aris Budiman \\ Teknik Elektro Universitas Muhammadiyah Surakarta
}

\begin{abstract}
Abstrak
Permasalahan $O P F$ terdiri dari banyaknya objective function, antara lain economic dispatch, perencanaan VAR, dan juga minimisasi rugi-rugi. Untuk perencanaan VAR perlu mempertimbangkan biaya operasional rugi-rugi, sehingga $D i$ tulisan ini secara perencanaan dan operasi yang simultan.

Quadratic Interior Point (IOIP). umum lebih baik dibanding metode IQIP ini memiliki unjuk kerja yang secara Quadratic Interior Point), antara la generasi sebelumnya, yaitu EQIP (Extended dan pada beberapa pengujian lain karena bisa menggunakan titik awal general menyebabkan metode IQIP keakuratan, dan konvergensi di menowarkan perbaikan besar di dalam kecepatan, objective function dan optimisasi yang multidari sistem terinterkoneksi dan sistem . Kemampuan memecahkan optimisasi global dari generasi sebelumnya.

Metode ini telah melalui pengujian terh

IEEE. Efektivitas dari metode pengujian terhadap sistem 14 bus, 30 bus, dan 118 bus program $O P F$ yang berbade ini telah dievaluasi dengan cara dibandingkan dengan MINOS yang cukup dikenal di dunia pextended Quadratic Interior Point) dan program
\end{abstract}

Kata Kunci: optimisasi, optimal power flow, interior point.

\section{Pendahuluan}

Perhitungan Optimal Power Flow (OPF) digunakan untuk menentukan variabel-variabel kendal optimal dan kuantitas sistem di dalam perencanaan dan operasi sistem tenaga listrik. Pertumbuhan jaringan dan tuntutan akan efisiensi dalam sistem kelistrikan membuat para pelaksana di dalam perencanaan dan operasi sistem tenaga listrik terus mencari metode yang cepat dan efisien untuk hal di atas.

Pada sekitar tahun 1980an mulailah digunakan metode Interior Point (IP) yang memberikan efisiensi dan kecepatan konvergensi yang tinggi. Dasarnya adalah pemrograman linier. Metode IP sederhana memiliki kekurangan, misalnya pada banyak kasus, metode ini tidak bisa memecahkan objective function

Selanjutnya Momoh berhasil membangun metode Extended Quadratic Interior Point (EQIP) yang mempu menangani objective function kuadratis dan kekangan yang linier maupun nonlinier. Ini dilengkapi dengan penanganan titik awal yang bagus dan kecepatan konvergensi yang lebih tinggi dibanding yang ada saat itu (sekitar 1995).

Di tulisan ini secara khusus hanya membahas metode OPF Improved Quadratic Interior Point (IQIP), yang diderivasikan dari objective function yang sudah biasa dikenal, yaitu economic dispatch, perencanaan VAR, dan minimisasi rugi, disertai dengan kekangan di dalam satu kesatuan lingkungan. Metode IQIP dilengkapi dengan titik awal general (lebih baik dari EQIP) dan secara umum lebih cepat dibandingkan EQIP. Sehingga metode IQIP yang dibahas di tulisan ini menawarkan perbaikan besar di dalam kecepatan, keakuratan, dan konvergensi di dalam pemecahan masalah optimisasi yang multiobjective function dan multi-constraint. Metode ini juga mampu memecahkan optimisasi global dari sistem terinterkoneksi dan sistem terpartisi untuk optimisasi lokal. Pembangkitan terjadwal, tap trafo, tegangan bus dan reaktor digunakan untuk mencapai penyelesaian aliran daya yang teroptimalkan dan layak.

Metode ini telah melalui pengujian terhadap sistem 14 bus, 30 bus, dan 118 bus IEEE. Efektivitas dari metode ini telah dievaluasi dengan cara 
dibandingkan dengan program OPF yang berbasis EQIP (Extended Quadratic Interior Point) dan program MINOS yang cukup dikenal di dunia perencanaan sistem.

\section{Rumusan Optimal Power Flow}

\subsection{Objective Function}

Di dalam tulisan ini, digunakan tiga buah objective function, yaitu minimisasi biaya bahan bakar, perencanaan VAR, dan minimisasi rugi-rugi.

- Minimisasi biaya bahan bakar

$$
\operatorname{Min} F_{g}=\sum_{i=1}^{N_{g}}\left(f_{i} P_{g i, l}^{2}+b_{i} P_{g i, l}+c_{i}\right)
$$

- Perencanaan VAR

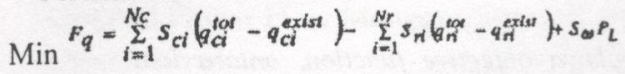

- Minimisasi rugi-rugi

$$
\operatorname{Min}_{L}=F\left(P_{\text {gslack }}\right)
$$

dengan

Pgi : pembangkitan daya nyata pada generator I

PL : Rugi daya sistem

Pgslack : daya nyata generator slack

Sc : biaya VAR kapasitif

$\mathrm{Sr} \quad$ : biaya VAR induktif

qc : dukungan VAR kapasitif

qr : dukungan VAR induktif

1 : kasus kontingensi, $1=0$ berarti kasus sempurna

S $\omega \quad$ : koefisien kopling antara porsi VAR dan rugi-rugi di dalam objective function perencanaan VAR

\subsection{Kekangan}

Kekangan baik linier maupun nonlinier, termasuk tegangan, aliran, pembangkitan nyata, sumber reaktif, dan tap trafo diperhitungkan sebagai berikut:

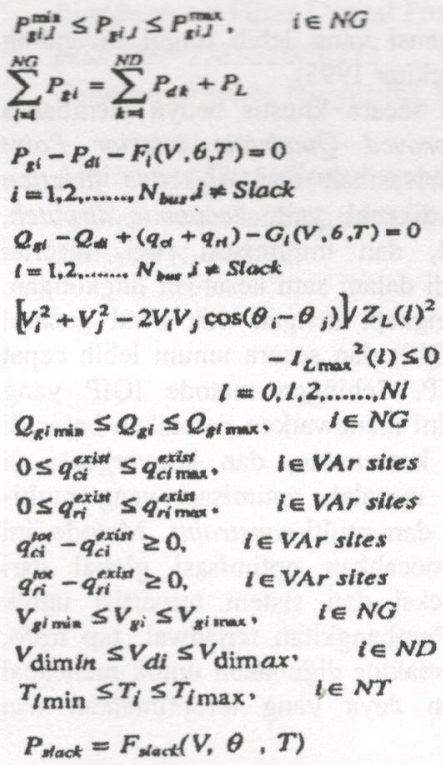

(10)

(11)

(12)
$\mathrm{V}_{\mathrm{gi}} \quad$ : magnitude tegangan pada bus generator I

$\mathrm{Q}_{\mathrm{gi}} \quad$ : pembangkitan VAR generator I

$\mathrm{Z}_{\mathrm{L}}$ : impedans saluran transmisi $\mathrm{L}$

$\mathrm{q}_{\mathrm{ci}} \quad$ : daya reaktif kapasitor pada bus I

$\mathrm{I}_{\mathrm{Lmax}}$ : batas arus maksimal yang lewat saluran transmisi L

T : posisi tap trafo

$\theta \quad$ : sudut tegangan pada bus I

$P_{L} \quad$ : rugi daya nyata sistem

$\mathrm{N}_{\mathrm{G}}$ : jumlah bus generator

$\mathrm{N}_{\mathrm{T}}$ : jumlah percabangan trafo

$\mathrm{N}_{\mathrm{D}}$ : jumlah bus beban

$\mathrm{N}_{\text {bus }}$ : jumlah bus jaringan total

$\mathrm{N}_{1}$ : jumlah saluran keluar $(1=0$ berarti tak ada saluran yang keluar)

Pengguna dapat mengambil kekangan tertentu dari (1)-(14) sesuai dengan kebutuhan pengguna. Secara umum, kekangan (1)-(6) dan $(11)-(13)$ dipertimbangkan untuk economic dispatch. Kekangan (2)-(14) dipertimbangkan untuk perencanaan VAR. Sedangkan untuk minimisasi rugi dipertimbangkan dalam kekangan (2)-(6) dan (11)-(14).

\section{Algoritma OPF IQIP}

\subsection{Diagram Alir Iterasi IQIP}

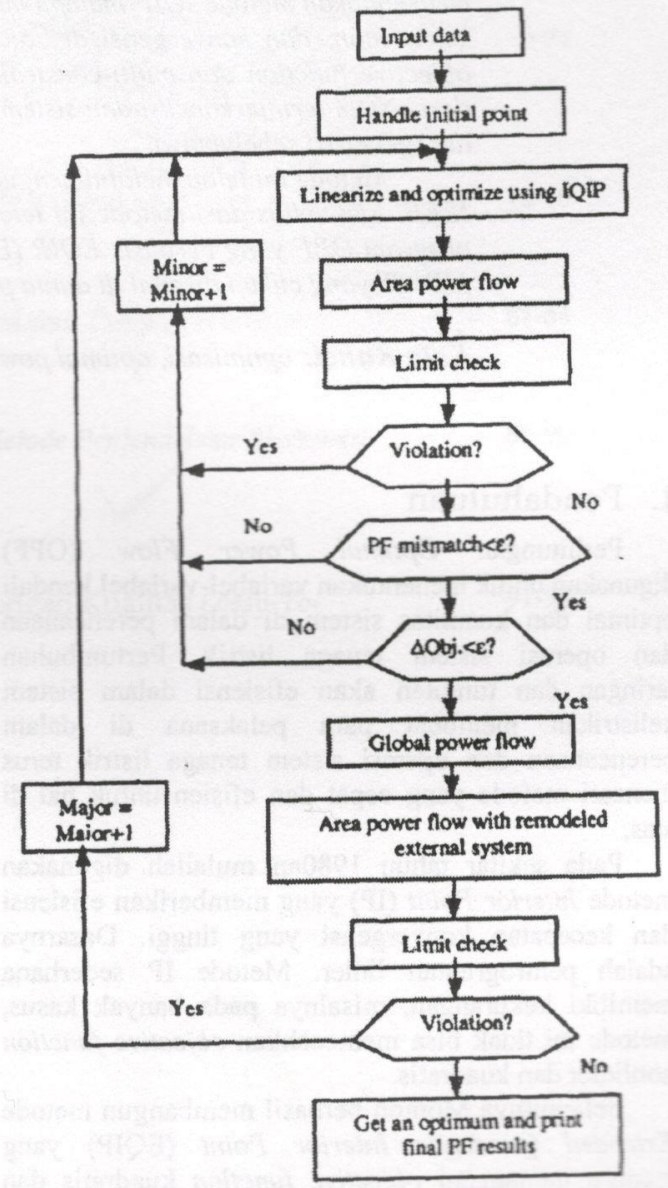

dengan

$\mathrm{P}_{\mathrm{dk}}$ : beban daya nyata pada bus beban $\mathrm{k}$

$\mathrm{Q}_{\mathrm{di}} \quad$ : beban daya reaktif pada bus beban I 
3.2. Metode Improved Quadratic Interior Point

Model OPF yang disebutkan di atas adalah sebuah permasalahan pemrograman matematis nonlinier. Dari model ini bisa dilakukan reduksi dengan prosedur eliminasi. Reduksi model OPF tersebut berdasar pada aliran daya yang dilinierkan melalui penyelesaian aliran daya pokok untuk gangguan kecil. Model OPF yang direduksi memiliki format:

Min

$$
F=\frac{1}{2} X^{T} Q X+G^{T} X+C
$$

Mengacu pada

$$
\mathrm{AX}=\mathrm{B} \text {, dengan } \mathrm{X}>0
$$

Persamaan 15 adalah fungsi skalar, yang berhubungan dengan objective function OPF. Persamaan 16 berhubungan dengan kekangan (1)-(14) dengan penanganan linierisasi. X di dalam persamaan 15 dan 16 adalah vektor dari variabel yang bisa dikendalikan, di mana didefinisikan sebagai

$\mathrm{X}=[\mathrm{VgT}, \mathrm{TT}, \mathrm{PgT}] \mathrm{T}$ di dalam economic
dispatch, atau

$\mathrm{X}=[\mathrm{VgT}, \mathrm{TT}, \mathrm{qcT}, \mathrm{qrT}, \mathrm{PLT}] \mathrm{T}$ di dalam perencanaan VAR

$\mathrm{X}=[\mathrm{VgT}, \mathrm{TT}, \mathrm{PLT}] \mathrm{T} \quad$ di dalam minimisasi rugi-rugi

Algoritma IQIP adalah sebagai berikut:
S1 given a starting point $\mathrm{X} 1$,

S2 A1: $=\mathrm{AX} 1$

S3 $\triangle:=B-A X 1$,

S4 $\Delta \max :=\max |\Delta \mathrm{i}|$,

S5 if $\Delta \max <\varepsilon 0$, go to $S 10$. Other wise,

S7 $U:=\left[A \mid\left(A \mid A I^{\top}\right)^{-1}\right] \Delta$.

$\mathrm{R}:=\min [\mathrm{Ui}\}$,

S8 if $R+1 \geq 0, \quad X 1:=X 1 *(1+U)$.

go to $S 3$. Otherwise,

S9 $\mathrm{QB}:=-1 / \mathrm{R}, \quad \mathrm{XI}:=\mathrm{X} 1^{*}(1+\mathrm{QB} * \mathrm{U})$, go to $S 3$,

S10 $D_{1}:=\operatorname{diag}[\times 1, \times 2, \ldots \ldots, \times n]$

S11 $B_{k}:=A D_{k}$

S12 $d p^{k}:=\left[B_{k}{ }^{\top}\left(B_{k} B_{k}{ }^{T}\right)^{-1} B_{k}-1\right] D_{k}\left[Q X^{k}+G\right]$,

S13 $\beta 1:=-1 / \gamma, \gamma<0 ; \beta 1:=10^{6}, \gamma \geq 0$,

(where $\gamma=\min \left[\mathrm{dp}_{j}{ }^{k}\right]$ ).

S14 $\quad \beta 2:=\left(d^{k}\right)^{T}\left(d p^{k}\right) / W, W>0, \beta 2:=10^{b}, W \leq 0$, [where $W:=\left(D_{k} d p^{k}\right)^{T} Q\left(D_{k} d p^{k}\right)$ ]

S15 $X^{k+1}:=X^{k}+\alpha\left(\beta D_{k} d^{k}\right)$

(where $\beta:=\min [\beta 1, \beta 2] ; \alpha$ is a variable step. Its value is less than 1.00 )

\section{Kesimpulan}

Dari pengujian yang telah dilakukan oleh Momoh dan Zhu untuk membandingkan performa penanganan OPF antara metode IQIP (yang diusulkan) dengan EQIP dan program jadi MINOS versi 5.1 diperoleh hasil bahwa ternyata IQIP mampu memberikan perbaikan besar terhadap kecepatan, akurasi, dan konvergensi di dalam penyelesaian masalah optimisasi multi-objective dan multikekangan.

Metode IQIP telah diuji menggunakan sistem 14 30, dan 118 bus IEEE untuk economic dispatch, perencanaan VAR, dan minimisasi rugi-rugi.

\section{Daftar Pustaka}

1] Momoh, J.A., Zhu, J.Z, Improved Interior Point Method for OPF Problems, IEEE Trans. on Power System, vol 14, Aug. 1999

[2] Papalexopoulos, A.D., Imparato C.F., Wu, F.F., Large Scale Optimal Power Flow: Effects of Initialization Decoupling and Discretation, IEEE Trans. On Power Systems, vol. 4, 1989, pp 748-759

3] Zhu, J,Z., Irving, M.R., Combined active and reactive dispatch with multiple objectives using an analytichierarchical process, IEEE Proceeding, Part C, vol 143, no.4, 1996, pp 344-352 